\title{
特集「「治療可能な認知症（treatable dementia）” の現在一その可逆性を考えるー」
}

\author{
腎臓と認知症 \\ 丸山高史
}

日本大学医学部内科学系腎臟高血圧内分泌内科

\section{The Relationship between Renal Disease and Dementia}

\author{
Takashi MARUYAMA
}

Division of Nephrology, Hypertension and Endocrinology, Department of Internal Medicine, Nihon University School of Medicine

Chronic kidney Disease (CKD) is strongly associated with Cardiovascular Disease. Particularly among Japanese, it is said that the kidney is closely associated with the brain. With respect to renal failure and dementia, the risk factors of dementia are common to those factors of internal medicine, such as hypertension, diabetes and factors associated with renal failure. Herein, we describe a mechanism and measure of dementia associated with renal disease, and consider the potential of treatable dementia.

Key words: Uremia, Diabetes, Hypertension

尿毒症，糖尿病，高血圧

(J. Nihon Univ. Med. Ass., 2018; 77 (5): 295-298)

慢性腎臓病 (CKD) の概念が 2002 年に米国腎臓財団 (NKF) から提唱されて久しいが, その定義は(1)尿異常, 画像診断, 血液, 病理で腎障害の存在が明らか, 特に蛋 白尿の存在が重要, (2) eGFR が $60 \mathrm{ml} / \mathrm{min}$ 以下のうち(1), (2)いずれかもしくは両方が 3 力月以上持続する場合とさ れる ${ }^{1)}$.

この CKD は心血管病発症と強く関連している。 とり わけ日本人は脳神経疾患との結びつき（脳腎連関）が深 い. CKD は脳卒中, 認知機能障害, 認知症を発症する リスクが高い。腎機能障害患者を対象とした横断研究 (Chronic Renal Insufficiency Cohort: CRIC) 研究では eGFR $<30 \mathrm{ml} / \mathrm{min} / 1.73 \mathrm{~m}^{2}$ 群では 45〜 $59 \mathrm{ml} / \mathrm{min} / 1.73 \mathrm{~m}^{2}$ 群と比
較して認知機能障害のリスクが $47 \%$ 増大することが示 された. 65 歳以上の高齢者を対象とした米国の調査で は, 中等度の腎障害（血清 $\mathrm{Cr}$ 值 : 男性 $>1.3 \mathrm{mg} / \mathrm{dl}$, 女 性 > $1.5 \mathrm{mg} / \mathrm{dl}$ ) が存在すると認知症リスクが $37 \%$ 増大 することが示された。この他にも国内外で行われた多く の横断研究, 前向き研究において CKD が認知機能障害, 認知症と連関することが報告されている. メ夕解析の結 果でも, CKD はその重症度に相関して認知機能障害と 連関することが示されている2).

腎不全と認知症についてその原因, 機序としては以下 の内容が考えられる（図 1). 大きく分けて 2 つ危険 因子があり 1 つは腎不全を二次的に併発する高血圧や糖

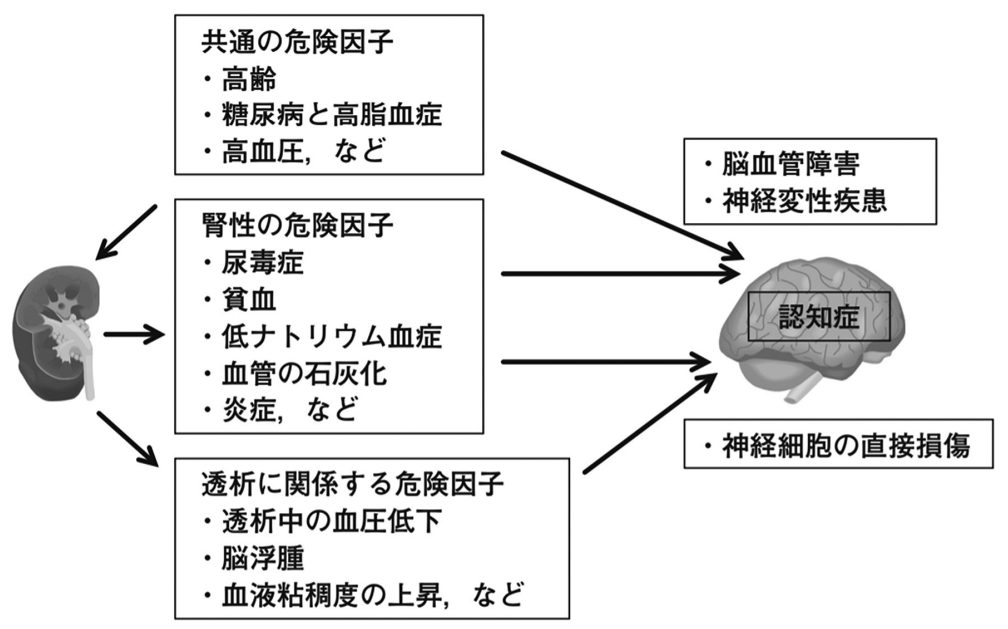

図 1 慢性腎臓病の認知症の原因

Kurella TM, Yaffe K: Dementia and cognitive impairment in ESRD: diagnostic and therapeutic strategies. Kidney Int, 79; 14-22, 2011. より 改変 
尿病の他に高脂血症や加齢など内科領域共通の危険因子 と, もう 1 つは保存期から透析期を含めた腎不全に関連 した危険因子および透析に関係する危険因子である。そ のため, 前者に対しては軽微な腎機能障害, 検尿異常に も注意を払い，血圧・血糖管理や食事療法を積極的に行 い，CKDを予防して脳腎連関に楔をうち入れることが 認知症の予防にもつながる。つまりこれらは病期の初期 からしっかり対応することで治療可能となる.

後者についてであるが, 進行する腎不全に対して適切 な治療が行われない場合, 尿毒素 (uremic toxin) 蓄積, 体温組成の変化により脳神経症状，精神症状を呈する (尿毒症性脳症：uremic encephalopathy), 意識障害, 高 次脳機能障害, 運動機能障害からなり, 尿毒症の進行と ともに重症化する。注意障害, 不眠, 感覚鈍麻から始ま り, 見当識障害, 幻覚, 傾眠傾向が出現し, ついには昏 睡状態へ陥る。羽ばたき振戦, 痤攣, 末梢神経障害等の 神経症状を付随する。一連の変化は基本的に可逆性であ り, 適切な血液浄化療法により改善する。これも治療可 能な認知症に入ると言えよう。血液透析施行中であって も，透析効率が不良な場合は生じることがあり，透析施 行中の患者に前述の症状が出現した場合には念頭に置く 必要がある。末期腎不全において透析開始の開始時期を 見誤らず，また透析効率に配慮した診療を行うことによ り認知症を予防, 治療が可能となる。1970 年代に一部 の欧米諸国を中心に, 透析患者に痤攣, 振戦, 高次脳機 能・認知機能障害を来し死亡にまで至る事例が報告され た (透析脳症)。当該地域では透析液に水道水を使用し, 過剰に含まれていたアルミニウムが脳内に蓄積すること が判明した（アルミニウム脳症）。わが国ではイオン交 換樹脂を用いた軟水装置, 逆浸透圧装置を用いて透析液 は高度に純化されており，典型例はほとんど報告されて いない ${ }^{3)}$ 。透析液の組成や血清アルミニウム值に注意を することで予防可能な認知症である。また一方同様の金 属でマグネシウムにおいて透析患者の場合, 下剤を連用 した場合に高マグネシウム血症を来して併発する場合が ある。この可能性の方が高アルミニウム血症に遭遇する よりも現在は頻度が高い。この場合意識障害などを来す 恐れがあるので注意が必要である。必要に応じて下剤を マグネシウム含有でない種類に変更が必要である.

これ以降は糖尿病と認知症について記す。糖尿病患者 ではアルツハイマー型認知症が約 1.5 倍前後, 血管性認 知症が 2.5 倍前後多い4)。このように糖尿病は血管性認 知症だけでなくアルツハイマー型認知症の危険因子にな ることが多くの疫学研究において示されている。アルツ ハイマー型認知症と糖尿病の関連について, 久我山町研 究は生前のインスリン抵抗性の存在が死後病理によりア ルツハイマー型認知症に特徵的であるアミロイド沈着と 関連することを示した，他の臨床研究においては主とし て神経細胞レベルでのインスリン抵抗性, 糖尿病による
最小動脈硬化，低血糖発作などがアルツハイマー型認知 症進行に重要な役割を演じていることが明らかになって いる。基礎研究からは経鼻インスリン療法やインスリン 感受性改善薬などの糖尿病性治療薬がアルツハイマー型 認知症の進行防止（病態修飾）薬として期待しうること を示唆している ${ }^{5)}$. 今後糖尿病による認知症に対して, また更にはそれ以外の認知症に対してもこれらの薬剤を 臨床応用することで治療出来るようになる可能性が有る.

わが国においては糖尿病性腎症が新規透析導入原疾患 の第一位であり，糖尿病透析患者も増加傾向にある。腎 機能が低下している場合，インスリンや経口血糖降下薬 のクリアランスの低下と腎での糖新生低下により，イン スリン作用が相対的に過多になることで低血糖が生じる. 腎での糖新生は腎重量の低下とともに進行し, 薬物によ る低血糖が起きた場合，対処しきれず低血糖が遷延する 傾向にある（図 2)，さらに糖尿病患者，特に高齢者に おいては食後高血糖や低血糖を起こしやすく，低血糖に 対する脆弱性を有する。低血糖の頻度と認知症の発症り スクとの間に関連が認められている $(\text { 図 } 3)^{6}$. 。 そのため, 低血糖を避けつつ，血糖值を綿密に測定し，薬物の投与 量を調整することが必要となる。低血糖がある患者の認 知症発症リスクは1.6〜2.4 倍であり, 認知症と低血糖は 悪循環を形成し得る ${ }^{7)}$. 重症低血糖以外の認知症のリス クファクターとして血糖変動が大きいこと委，食後高血 糖 $^{9)}$ ，インスリン抵抗性 ${ }^{10)}$, 脳血管障害多発 ${ }^{11)}$, 収縮期 高血圧 $^{12}$, 脂質異常症 ${ }^{12)}$, さらには高血糖が挙げられる. ただし高血糖については血糖を下げることで認知症の発 症, 進行を防止出来るかを調査した RCT は極めて少な い. $\mathrm{HbA} 1 \mathrm{c} 7 \%$ 未満を目標にした強化療法群では 5 年間 の認知機能低下が緩徐であったという報告がある ${ }^{13)}$ 一 方, HbA1c 6\%未満と 7〜 7.9\%を目標にした通常治療群 では前者では脳容積は大きかったものの, 認知機能は差 を認めなかった ${ }^{14)}$. 認知機能低下抑制のための適切な血 糖コントロール目標の設定に関しては更なるエビデンス の蓄積が必要と考えられる ${ }^{15)}$. 糖尿病患者の認知機能低 下の予防には血管リスクの包括的管理が重要視されてい る. 現時点では特定の糖尿病治療薬や血糖コントロール が認知症を予防できるかに関してのエビデンスはないが, 低血糖は避けるべきと考えられている。低血糖が生じた 場合，その原因が何であったかを検証し，再発を防止す ることが重要である，透析中の患者を含め，腎機能が低 下している場合，血糖值を綿密に測定しながら，インス リン投与量や経口薬の用量調節を行っていくことが, 低 血糖対策として重要である。

一般の糖尿病診療において, 現在の参考となる指標に ついて表 1 を参照されたい ${ }^{16)}$ ，要点として SU 用やイン スリンなどの重症低血糖の危惧される薬剤を使用してい ない場合で認知症や基本的 ADL 低下がないカテゴリー $\mathrm{I} \sim$ II の場合は, 従来の合併症を防ぐための目標值であ 


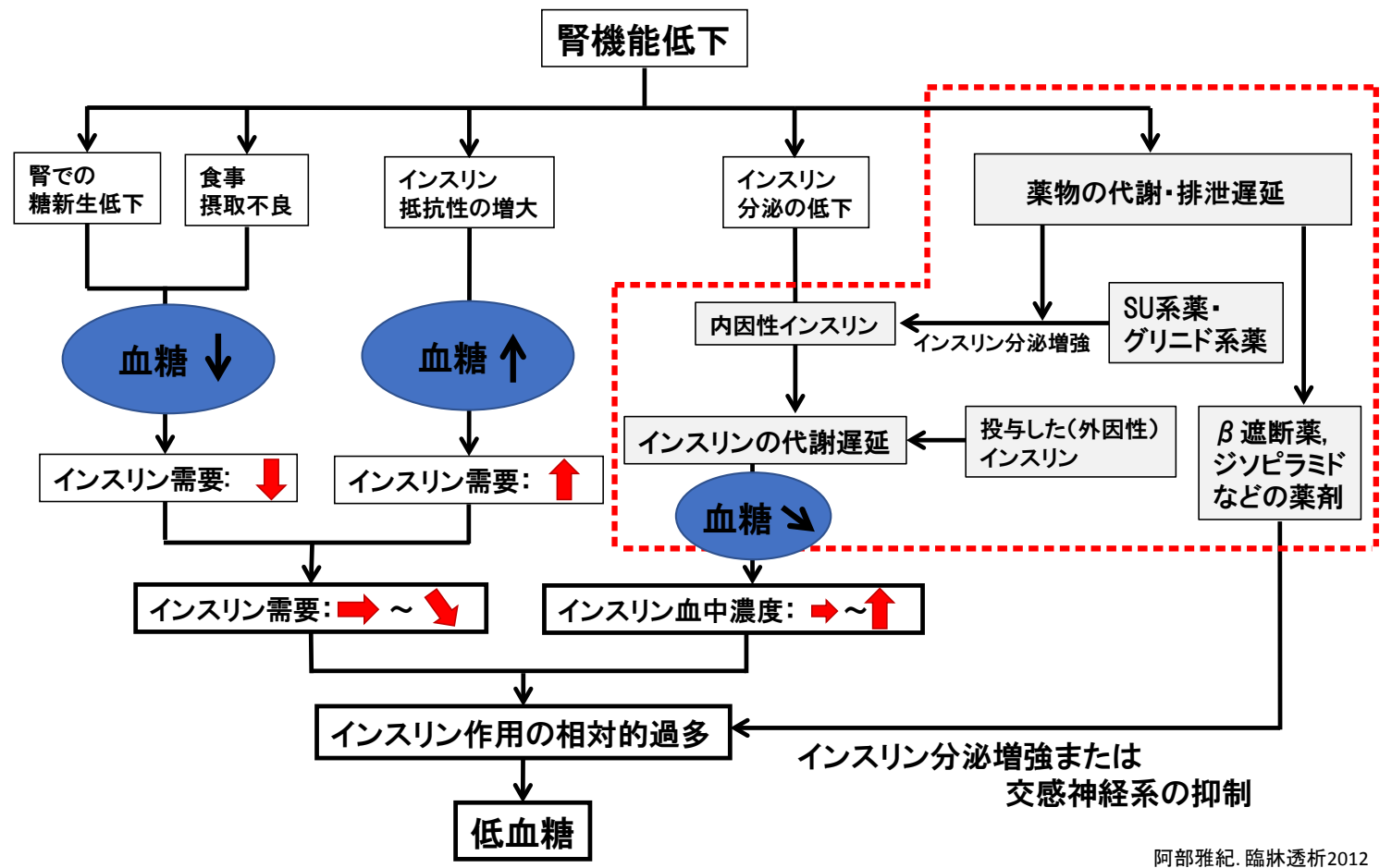

図 2 腎機能低下時の低血糖発症機序

阿部雅紀 他． 糖尿病腎症進行過程における低血糖出現の機序とその対策. 臨牀透析 2012; 28: 189-197.

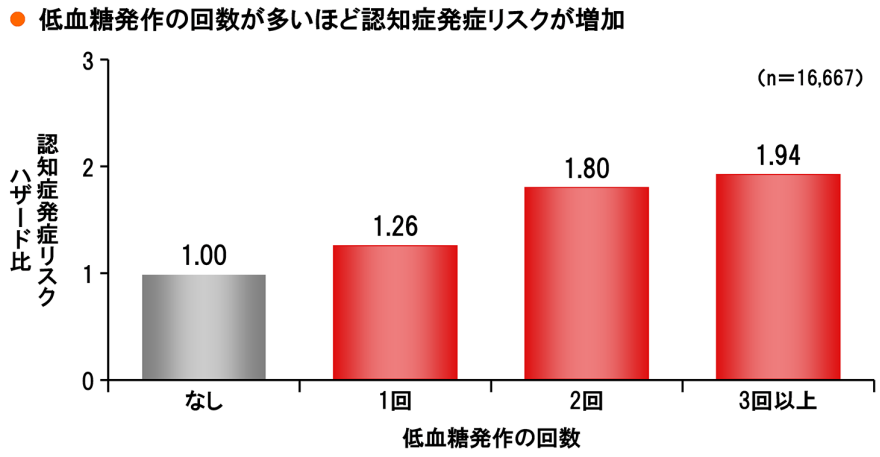

図 3 低血糖と認知症発症リスク

方法：16,667 人の高齢糖尿病患者で, 重症低血糖の発現回数と認知症発症の関係を解析した。低血糖の観察期間：1980 年 1 月 ～ 2002 年 12 月，認知症の発症の観察期間： 2003 年以降（平均観察期間：3.8 年）年齢，BMI，人種，教育，性別，糖尿病の罹 病期間, 併存疾患, HbA1cの 7 年平均, 糖尿病治療, インスリンの使用年数をマッチングさせ解析.

Whitmer R, et al.: JAMA. 301: 1565-1572, 2009. より作図

表 1 高齢者糖尿病の血糖コントロール目標 ( $\mathrm{HbAl} 1 \mathrm{c}$ 值 $)$

\begin{tabular}{|c|c|c|c|c|c|}
\hline & & \multicolumn{2}{|c|}{ カテゴリーI } & カテゴリーII & カテゴリーIII \\
\hline \multicolumn{2}{|c|}{ 患者の特徵·健康状態注 1) } & \multicolumn{2}{|c|}{$\begin{array}{l}\text { (1)認知機能正常 } \\
\text { 力口 } \\
\text { (2) ADL 自立 }\end{array}$} & $\begin{array}{l}\text { (1)軽度認知障害 } \\
\text { 軽度認知症 } \\
\text { または } \\
\text { (2)手段的ADL低下, } \\
\text { 基本的 ADL 自立 }\end{array}$ & $\begin{array}{l}\text { (1)中等度以上の認知症 } \\
\text { または } \\
\text { (2)基本的 ADL 低下 } \\
\text { または } \\
\text { (3)多くの併存疾患や } \\
\text { 機能障害 }\end{array}$ \\
\hline \multirow{3}{*}{ 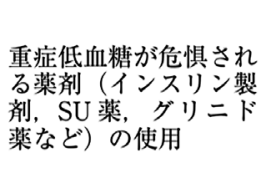 } & なし注2) & \multicolumn{2}{|c|}{$7.0 \%$ 未満 } & $7.0 \%$ 未満 & $8.0 \%$ 末満 \\
\hline & \multirow{2}{*}{ あり注3) } & $\begin{array}{l}65 \text { 歲以上 } \\
75 \text { 歳未満 }\end{array}$ & 75 歳以上 & \multirow{2}{*}{$\begin{array}{c}8.0 \% \text { 未泗 } \\
\text { (下限 } 7.0 \%)\end{array}$} & \multirow{2}{*}{$\begin{array}{c}8.5 \% \text { 未満 } \\
\text { (下限 7.5\%) }\end{array}$} \\
\hline & & $\begin{array}{c}\text { 7.5\% 未渵 } \\
\text { (下限 } 6.5 \%)\end{array}$ & $\begin{array}{l}8.0 \% \text { 未満 } \\
\text { (市限 7.0\%) }\end{array}$ & & \\
\hline
\end{tabular}


る HbAlc 7.0\%未満となっている。一方, 重症低血糖の 危惧される薬剤を使用している場合は, 目標值が表のと おり高めに設定されている。これは HbAlc 7.0\%未満で は重症低血糖やそれと関連する弊害が多くなるからであ る。したがって，目標下限值を下回った場合は無自覚性 も含めて低血糖がないかを評価をすることが大切であ る ${ }^{17)}$. これが認知症予防にもつながると考えられる。

以上腎疾患と認知症について述べてきた。前述のとお り腎領域では末期腎不全の際の尿毒症そのものが認知症 の危険因子となる場合と, 腎機能障害を併発する高血圧 や糖尿病の他, 高脂血症や加齢など内科共通危険因子に よる認知症の 2 種類が主に存在する。今回のテーマは治 療可能な認知症ということであるが，予防という観点か らも含めて述べさせて頂いた。診療の一助になれば幸い である。

\section{文献}

1）日本腎臓学会編. CKD 診療ガイド 2012; 1-4.

2) Etgen $T$, et al. Chronic Kidney Disease and Cognitive Impairment. A Systematic Review and Meta-Analysis. American Journal of Nephrology 2012; 35: 427.

3) 柏原直樹。慢性腎臓病 (CKD) と脳神経疾患。日本内科 学会誌 2012; 101(8): 2195-2203.

4) Cukierman T, Gerstein HC, Williamson JD. Cognitive decline and dementia in diabetes-systematic overview of prospective observational studies. Diabetologia 2005; 48: 2460-2469.

5）笠井高志．認知症と糖尿病．京都府医大誌 2017; 126(10): 697-705.

6) Whitmer RA, Karter AJ, Yaffe K et al. Hypoglycemic episodes and risk of dementia in older patients with type 2 diabetes mellitus. JAMA301 2009; 1565-1572.
7) Yaffe K, Falvey CM, Hamilton $\mathrm{N}$ et al. (Health ABC Study). Association between hypoglycemia and dementia in a biracial cohort of older adults with diabetes mellitus. JAMA Intern Med 2013; 173: 1300-1306

8) Rizzo MR, Marfella R, Barbieri M et al. Relationships between daily acute glucose fluctuations and cognitive performance among aged type 2 diabetic patients. Diabetes Care 2010; 33: 2169-2174.

9) Cui X, Abduljalil A, Manor BD et al. Multi-scale glycemic variability: a link to gray matter atrophy and cognitive decline in type 2 diabetes. PLoSOne 2014; 9: e86284.

10) Matsuzaki T, Sasaki K, Tanizaki $Y$ et al. Insulin resistance is associated with the pathology of Alzheimer disease: the Hisayama study. Neurology 2010; 75: 764-770.

11) Araki A, Ito H. Asymptomatic cerebral infarction on brain MR images and cognitive function in elderly diabetic patients. Geriatr Gerontol Int 2002; 2: 206-214.

12) Umegaki $H$, Iimuro $S$, Shinozaki $T$ et al. Risk factors associated with cognitive decline in the elderly with type 2 diabetes. Pooled logistic analysis of a 6-year observation in the Japanese elderly diabetes intervention trial (J-EDIT). Geriatr Gerontol Int 2012; 12(Suppl 1): 110-116.

13) Luchsinger JA, Palmas W, Teresi JA et al. Improved diabetes control in the elderly delays global cognitive decline. $J$ Nutr Health Aging 2011; 15: 445-449.

14) Launer LJ, Miller ME, Williamson JD et al. Effects of intensive glucose lowering on brain structure and function in people with type 2 diabetes (ACCORD MIND): a randomised open-label substudy. Lancet Neurol 2011; 10: 969-977.

15）日本糖尿病学会編。糖尿病診療ガイドライン 2016; 411422.

16）日本糖尿病学会編．糖尿病治療ガイド 2016-2017；2016 97-98.

17）荒木 厚, 井藤英喜.「高齢者糖尿病診療ガイドライン 2017」を踏まえた治療の要点と展望. 日本老年医学会雑 誌 2018; 55(1): 1-12. 